\title{
Yıkıcı Liderliğin Örgütsel Sapmaya Etkisinde Örgütsel Sinizmin Rolü: Konya İli Gıda Sektöründe Bir Uygulama
}

\section{The Role of Organizational Cynicism in the Effect of Destructive Leadership on Organizational Deviation: A Food Sector Research in Konya}

Ahmet Tuncay Erdem a,*

${ }^{a}$ Dr. Öğr. Üyesi, Bolu Abant İzzet Baysal Üniversitesi, İletişim Fakültesi, 14100, Bolu/Türkiye. ORCID: 0000-0003-4573-8415

\section{MAKALE BİLGİSI}

Makale Geçmişi:

Başvuru tarihi: 02 Kasım 2020

Düzeltme tarihi: 15 Şubat 2021

Kabul tarihi: 21 Şubat 2021

Anahtar Kelimeler:

Y1kıcı Liderlik

Örgütsel Sapma

Örgütsel Sinizm

\section{ARTICLE INFO}

\section{Article History:}

Received 02 November 2020

Received in revised form 15 February 2021

Accepted 21 February 2021

\section{Keywords:}

Destructive Leadership

Organizational Deviance

Organizational Cynicism

\section{ÖZ}

Yıkıcı liderlik davranışları, iş yaşamında çalışanlarla yöneticilerin ilişkilerinde güvensizliğe neden olmakta, örgütte çeşitli sorunlara yol açabilmektedir. Bu araştırmanın temel amacı, yıkıcı liderlik davranışlarının örgütsel sapmaya etkisinde "örgütsel sinizm"in aracı işlev görüp görmediğini belirlemektir. Araştırma nicel araştırma yöntemine göre tasarlanmıştır. Araştırma verileri, Konya gıda üretim sektöründe faaliyet gösteren bir işletmeden $(n=283)$ tam sayım örnekleme tekniğine göre toplanmıştır. Araştırmada betimsel analizler, fark ve ilişki testleri yapılmıştır. Araştırma verilerinin analizinde elde edilen bulgulara göre yıkıcı liderlik davranışının, örgütsel sapma ve örgütsel sinizme pozitif etkileri belirlenmiştir. Yıkıcı liderliğin örgütsel sapmaya etkisinde örgütsel sinizmin aracı rolü olduğu belirlenmiştir. Sonuç olarak yıkıcı liderlik davranışı olumsuz bir davranış olarak örgütte çalışanlara yönelik olumsuz davranışları tetiklemektedir. Olumsuzluğun yöneticiden gelmesiyle de çalışanlarda örgütsel sapma ve sinizm algılarının artması görülebilir.

\section{A B S T R AC T}

Destructive leadership behaviors cause insecurity in the relationships between employees and managers in business life and can lead to various organizational problems. This study's main purpose is to determine whether "organizational cynicism" functions as a mediator in the effect of destructive leadership behaviors on organizational deviation. The research is designed according to the quantitative research method. Research data were collected from an enterprise operating in the Konya food production sector $(n=283)$ using the full count sampling technique. Descriptive analysis, difference, and relationship tests were carried out in the research. According to the findings obtained from the research data analysis, the positive effects of destructive leadership behavior on organizational deviation and organizational cynicism were determined. It has been determined that organizational cynicism has a mediating role in the effect of destructive leadership on the organizational deviation. As a result, destructive leadership behavior triggers negative behaviors towards employees in the organization as a negative behavior. It can be seen that the perceptions of organizational deviation and cynicism increase in the employees as the negativity come from the manager.

\section{Giriş}

Liderlik, belirli grup veya topluluktaki insanları ortak bir amaç etrafında toplayarak bu amaçların gerçekleştirilebilmesi için onları harekete geçirebilme yetenek ve bilgilerin toplamıdır (Eren, 2001: 390). Liderlik, çalışanları etkileme, ikna etme, motive ederek destekleme süreci olmakla birlikte bireylerin ilişkilerini olumlu yönde etkileyerek takım ruhu oluşturma, ortak amaçları gerçekleştirme ve verilen görevleri en etkili biçimde yaptırma yöntemidir (Hogan ve Kaiser, 2005: 170; Başar ve Basım, 2018; Robbins ve Davidhizar, 2020: 118). Bu kapsamda bireylerin amaçları gerçekleştirebilmeleri noktasında bir yol gösterici olan lider, sıradan insanlara olağanüstü işler yaptıran kişi olarak da nitelendirilmektedir

\footnotetext{
* Sorumlu yazar/Corresponding author.

e-posta: ahmeterdem@ibu.edu.tr
} 
(Aslan, 2019: 20). Liderler örgütlerde her ne kadar çalışanları motive eden ve verimli çalışmalarını teşvik eden bireyler olmalarına karşın bazı durumlarda davranışlarının olumsuz olması sebebiyle örgütlerde çalışanların olumsuz örgütsel davranışlar sergilemelerine neden olabilir (Einarsen vd., 2007).

Liderlik kavramını konu alan araştırmalar genel olarak liderliğin oluşum biçimi ve içeriği (Charan, 2017; Sarıçam, 2017; Gün ve Aslan, 2018; Hse, 2018; McKenna ve Rooney, 2019; Wade ve Obwegeser, 2019; Bolea ve Atwater, 2020; De Lima, 2020; Petrone, 2020), yapıcı ve etkili liderin nasıl olunduğu (Mehmet vd., 2004; Tüysüz, 2007; Bakan ve Doğan, 2012; Tabak vd., 2013; Coker, 2020; Düğer, 2020; Suyono vd., 2020; Topaktaş, 2020), liderlik türlerinin neler olduğu (Gandolfi ve Stone, 2016; Park vd., 2016; Sarto ve Veronesi, 2016; Yeşil, 2016; Kim, 2017; Alper ve Çetin, 2018; Çalışal ve Yücel, 2019; Gnambs, 2019; Egide ve Andala, 2020; Farah vd., 2020; Karacabey vd., 2020) gibi liderliğin olumlu yönlerini ön plana çıkarmaya yönelik çalışmalardan oluşmaktadır. Diğer yandan liderlerin her durumda olumlu davranışlarda bulunmaları, toplum ve grupları etik davranışlara yöneltmeleri de her zaman beklenmeyebilir. Reyhanoğlu ve Akın (2016: 444), çalışanların tutum ve davranışları ile moral ve motivasyonlarını etkileme yönünden liderin önemli olduğunu belirterek örgüt içerisinde liderin olumsuz davranışlar sergilemesiyle örgüt ikliminin olumsuz etkilenerek çalışanların motivasyonunu düşüreceğini ve bu durumun örgütün zarar görmesine neden olacağını belirtmektedir. Bu durumlar liderliğin karanlık yönü olarak gösterilmekle birlikte yıkıcı liderlik de liderliğin karanlık yönlerinden birisi olarak alan yazında belirtilmektedir (Krasikova vd., 2013: 1310). Y1kıcı liderlik örgütlerde çalışanları olumsuz etkileyen sapkın bir davranış olmakla birlikte bu liderlik özelliğinin çalışanlarda sinizme yol açtığı ve bu kapsamda çalışanların örgütsel sapmaya uğradıkları düşünülmektedir. Bu kapsamda araştırmada yıkıcı liderliğin sebep olabileceği olumsuz örgütsel davranış durumları (örgütsel sapma ve örgütsel sinizm) belirlenmeye çalışılarak yıkıcı liderliğin örgütleri olumsuz etkilediği belirlenmeye çalışılması ve bu liderlik türünün diğer olumsuz davranışları tetikleyebileceğini göstermesi açısından önemlidir.

Örgütlerde başarısız ve hatalı uygulamalar sonucunda meydana gelen sorunlar ile yaşanan krizler, çalışanlara yönelik güvensizlik, monotonluk, yılma ve tedirginlik çalışanların örgüte yabancılaşmasına, tutum ve davranışlarının olumsuz yönde etkilenmesine sebep olmaktadır (Gül ve Ağıröz, 2011: 28; Çark ve Marşap, 2019; Bolea ve Atwater, 2020: 47). Sinizm ve sapma davranışlarının örgütte yaygın olarak görülmesinde önemli sebepler arasında çalışanların sahip oldukları doğruluk, dürüstlük, kanaat ve içtenlik gibi ahlaki değerlerin liderin bireysel çıkarları için feda edilmesi ve yok sayılmasıdır (James, 2005: 27). Diğer yandan alan yazında örgütsel sinizm ve örgütsel sapma durumlarının görülmesinde birçok etken bulunmaktadır. $\mathrm{Bu}$ etkenler arasında örgüt ile çalışanlar arasındaki uyumsuzluk, uzun ve yorucu mesai saatleri, niteliksiz insan kaynakları yönetimi, yöneticilere verilen dengesiz güç dağılımı gibi yönetim kaynaklı birçok faktör yer almaktadır (Andersson ve Bateman, 1997: 451; Ferres ve Connell, 2004: 62; James, 2005; Özgener vd., 2008: 57; Coker, 2020; Aboramadan vd., 2020). Bu olumsuz durumların genelinde lider veya yöneticinin çalışanlara yönelik yanlış ve yıpratıcı davranışlarının olduğu bilinmektedir.

Yıkıcı liderlik davranışı sonucunda meydana geldiği düşünülen örgütsel sinizm ve örgütsel sapma gibi sapkın davranışlar günümüzde bütün örgütler için olumsuz sonuçlar doğurmaktadır (Bennett ve Robinson, 2003: 247). Amerika'da bir araştırma kuruluşunun yaptığı araştırmaya göre örgütsel sapma oranı 2000'li yıllarda önceki yıllara göre \% 95 artış göstermiştir (Appelbaum vd., 2007: 587). Buna ek olarak her yıl dünya genelinde örgütlerde çalışanların yıkıcı liderliğin olumsuz etkileri nedeniyle meydana gelen sorunlarla baş etmeye çalıştıkları bilinmektedir. Amerika'da her yıl çalışanların yaklaşık 1,5 milyonu örgütte şiddet mağduru olurken, yarım milyonu da yanlış yönetim sonucunda soygun ve cinayet gibi suçlardan mağdur olmaktadır (Bennett ve Robinson, 2003: 247). Bu kapsamda yeterince doğru yönetilemeyen ve yanlış liderlik tarzı belirlenmiş örgütlerde sapkınlık davranışı görülerek çalışanlarda sinizm meydana gelmekte ve bu durumun Amerika'da örgütlere maliyetinin yıllık 50 milyarı aştığı tahmin edilmektedir (Appelbaum vd., 2007).

Alan yazında yıkıcı liderlik konusun hakkında yapılan araştırmalar genel olarak bu liderlik türünün örgütte olumsuz durumlara yol açtığına vurgu yapılmaktadır (Krasikova vd., 2013). Bu kapsamda araştırmada yıkıcı liderliğin yol açabileceği örgütsel sinizm ve örgütsel sapma konuları üzerinde durulmaktadır. Araştırmanın temel sorunu olumsuz ve yanlış liderlik yönteminin neden olduğu yıkıcı ve sapkın davranışların her geçen gün örgütleri olumsuz etkilemesidir. $\mathrm{Bu}$ çerçevede araştırmanın temel amacı; yıkıcı liderlik, örgütsel sapma ve örgütsel sinizm etkileşimlerini analiz etmek olup araştırma sorusu "Ylkıcı liderliğin örgütsel sapmaya etkisinde örgütsel sinizm aracl bir etkiye sahip midir" şeklinde belirlenmiştir. Araştırma gıda sektöründe yapılmıştır. Gıda sektörüne yönelik çalışanların işlerinin hassasiyetlerinden dolayı titiz çalışmaları, standart bir kalitede ürün üretmeleri gerekmektedir. Gıda işletmelerindeki liderlik ve yöneticilik davranışlarının çalışanları olumlu olarak etkileyerek çalışanların işlerini sabote etmeden yapmalarının gerekli olduğu düşüncesiyle araştırma uygulaması gıda sektöründeki çalışanlara yönelik yapılmıştır.

Bilimsel bilgiler önceki bilgiler ve deneyimlere dayalı olarak ortaya çıkmaları nedeniyle bilimsel araştırmalar kuramsal yaklaşımlara dayandırılmalıdır (Tutar ve Erdem, 2020: 123). Bu çerçevede araştırmanın yıkıcı liderlik değişkenine ilişkin kuramsal temeli davranışsal teoriye dayandırılmıştır. Araştırmanın ikinci değişkeni olan örgütsel sinizmin kuramsal temeli beklenti kuramına ve örgütsel sapma değişkeninin kuramsal temeli ise iş yeri saldırganlığı kuramına dayandırılmıştır.

\section{Kavramsal Çerçeve}

\subsection{Y1k1c1 Liderlik}

Liderlik kavramı alan yazında genel olarak yapıcı davranışlar üzerinde odaklanmasına rağmen, Einarsen vd. (2007) ilk olarak yapıcı liderlikten ziyade yıkıcı liderlik davranışının da örgütlerde meydana geldiğini belirtmektedir. Yıkıcı liderlik davranışı kavramını ilk ortaya atan Einarsen vd. 'ne (2007) göre liderler, örgütün menfaatlerini, 
amaçlarını, faaliyetlerini ve kaynaklarını etkin ve verimli bir şekilde gözetmek yerine astlarının motivasyon ve verimliliklerini azaltma pahasına kendi kişisel menfaatleri doğrultusunda liderlik pozisyonunu kullanarak yöneticilik davranışları sergileyebilirler. Padilla vd. (2007) yıkıcı liderlik kavramını daha faklı bir bakış açısıyla geliştirerek bu kavramı toksik liderlik olarak tanımlamıştır.

Yıkıcı liderler, örgütlerin uzun vadeli örgütsel hedefleri yerine kısa vadeli olan kendi kişisel kazançlarını tercih ederek, örgüt üyelerinin zararı pahasına işlemler yaparlar (Illies ve Reiter-Palmon, 2008). Bu noktada liderliğin karanlık yönünü oluşturan yıkıcı liderlik, örgüt iklimini olumsuz yönde etkileyerek, çalışanların iş tatminlerini azaltmakta ve tükenmişliklerine neden olmaktadır (Padilla vd., 2007; Shaw vd., 2011; Krasikova vd., 2013). Kasalak ve Aksu' ya (2016: 677) göre yıkıcı lider, kişisel çıkarlarının mesleki ideallerinin önüne geçmesiyle diğer çalışanlar ile sorunlar yaşamakta ve baskıcı tutumlar sergileyerek saygısızca davranışlarda bulunmaktadır.

Alan yazında yıkıcı liderlik hakkında birçok araştırma bulunmakla birlikte bu araştırmalarda yıkıcı liderliğin saldırgan bir davranış olduğu (Einarsen vd., 2007; Mitchell ve Ambrose, 2007; Aasland vd., 2010), çalışanların psikolojik ve fiziksel sağlıklarını, aile yaşamlarını, iş ve yaşam memnuniyetlerini olumsuz yönde etkileyerek takipçilere açıkça zarar verdiği (Hoobler ve Brass, 2006; Tepper vd., 2007; Schyns ve Hansbrough, 2010; Thoroughgood vd., 2012), çalışanlarda tükenmişlik duygusu oluşturduğu (Telli vd., 2012; Breevaart vd., 2014; Akman, 2016; Güldü ve Aksu, 2016; Uzunbacak vd., 2019; Brandebo, 2020; Kaluza vd., 2020) vurgulanmaktadır. Ayrıca yıkıcı liderliğin sapkın ve örgütte olumsuz davranışlara neden olduğu da belirtilmektedir. Buna ek olarak Aboramadan vd. (2020), örgütlerde yıkcı liderlik davranışlarından narsist liderlik davranışı sergilemenin çalışanlarda olumsuz davranışlara sebebp olabileceğini belirtmektedir.

Alan yazında yıkıcı liderlik, davranışsal teoriden yararlanılarak tartışılmaktadır (Aasland vd., 2010; Krasikova vd., 2013; Omar vd., 2015). Davranışsal teori liderin sahip olduğu özelliklerden ziyade astlarına davranış biçimi üzerine odaklanmaktadır. $\mathrm{Bu}$ teoride liderin takipçilerine davranışları kapsamında iletişim, planlama ve kontrol biçimleri üzerinde durulmaktadır (Aslan, 2019: 138). Yıkıcı liderlik davranışsal kuram kapsamında incelendiğinde; bu kişiler astlarını istismar etme yoluna giderek örgütün hedeflerine ulaşmada ters bir çaba göstermekte, yasa dışı davranışlara da başvurarak örgütün meşru menfaatlerinin aksine kendi kişisel çıkarlarına odaklanma davranışı göstermektedir. Buna ek olarak yıkıcı liderler ani yanlış davranışlar ile öfke patlaması gibi tekrarlayan olumsuz ve yıkıcı davranışlarla astlarını olumsuz yönde etkilemektedir (Aasland vd., 2010: 439).

\section{2. Örgütsel Sinizm}

Sinizm kavramı Antik Yunan döneminde Sinikler okulunun yer aldığı Atina yakınlarındaki Cynosarges adlı kasabada Sokrates'in öğrencisi Antisthenes tarafından ortaya atılmıştır. Daha sonra fıçı içerisinde hayatını devam ettiren Diogenes tarafindan yaygınlaşması sağlanarak sinikler olarak nitelendirilmiştir (Gökçe vd., 2017: 82). Sinikler örgütlerin, devlette dâhil olmak üzere insan yaşamına müdahil olamadan doğal bir form oluşturamayacağını savunmakta ve sinizme yönelik bireylerin felsefi olarak tamamen kendi kişisel çıkarları doğrultusunda hareket edeceklerini varsaymaktadır (Vice, 2011: 171). Bu kapsamda Antik Yunan filozofları tarafından sinizmin ortaya atılmasındaki amaç, sinizmin bireylerin kişisel çıkarları doğrultusunda hareket etmeleri bir kişilik özelliği olarak kabul edilmektedir. Ancak sinizm günümüzde örgütsel davranış çalışmalarına da konu olmakta birlikte örgütsel sinizmin meydana gelmesinde, çalışanların örgütte karşılaştıkları olumsuz davranışların etkili olduğu savunulmaktadır (Tutar, 2016: 78).

Örgütsel sinizm çok yönlü bir kavram olmakla birlikte kelime kökeni olarak felsefe temelli bir kavram olup başta yönetim olmak üzere sosyoloji, psikoloji, politik bilimler ile din gibi farklı disiplinlerde sıklıkla araştırılan konu olarak görülmektedir (Van Oortmerssen vd., 2020: 2258). Genel olarak sinizm bir yaşam biçimi, davranış türü, bir çözülme ve kopukluk olmakla birlikte; bireyin örgüt veya diğer bireylere yönelik sahip olduğu güvensizlik duygusuyla şüphecilik hissetmesidir. Buna ek olarak örgütsel sinizmde insanların az değerli olduğu düşünülerek sadece menfaatleri doğrultusunda hareket ettiklerine inanılmaktadır (Vice, 2011: 172).

Örgütlerde sinizmin ortaya çıkma sebepleri arasında; fazla mesai saatleri, yoğun iş temposu, çalışana yüklenen istenmeyen görevler, örgütlerin küçülmesi ve liyakatsiz, yeteneksiz ve yetkisiz yönetim ile olumsuz liderlik uygulamaları gösterilmektedir (Cartwright ve Holmes, 2006: 201). Diğer yandan çalışanlara yönelik psikolojik sözleşme ihlalleri, yönetime dâhil olamayarak karar almada dışlanma, örgüt içerisinde düşük etkileşim ve iletişim, örgütsel karmaşıklık, çalışanları susturmaya yönelik baskılar da sinizm nedenleri arasında gösterilmektedir (Karacaoğlu ve İnce, 2012; Yıldız, 2013). Bu olumsuz durumlar karşısında çalışanlar, kendi iyi niyetlerinin suiistimal edildiğine inanarak adalet, dürüstlük ve erdem gibi ilkelerin liderin kişisel çıkarları uğruna feda edildiğine inanmaktadır (Karacaoğlu ve İnce, 2012).

Örgütsel sinizm hakkında yapılan araştırmalarda (Akatay vd., 2016; Biswas ve Kapil, 2017; Özgen ve Turunç, 2017; Erdogdu, 2018; Kwantes ve Bond, 2019; Şamdan ve Baskan, 2019; Çevik ve Can, 2020; Kaya, 2020; Samat, 2020; Serinikli, 2020; Aboramadan vd., 2020) sinizmin; örgütsel adalet, örgütsel vatandaşlık, algılanan destek, çalışan sesliliği gibi örgüt için olumlu davranış ve durumlara negatif etkisinin olduğu görülmekle birlikte sinik bireylerin örgütte olumsuz davranışlar sergilediği belirtilmektedir.

Araştırma kapsamında örgütsel sinizm, beklenti kuramına dayandırılmaktadır. Kurama göre bireyler, ekonomik çıkarları doğrultusunda rasyonel davranışlar sergileyerek karşılarına çıkan seçeneklerden kendileri için en uygun ve en avantajlı alternatifi seçme eğiliminde olurlar. Bu kapsamda bireyler seçeneklerin farkına vararak kendi kapasiteleri doğrultusunda tercihlerde bulunurlar (Vroom, 1964: 16). Bu kuram güdülenmeye yönelik bir kuram olup, örgütte çalışanların göstermeleri beklenen çabalar ile bu çabaların beklenen sonuçlara ulaşma ihtimali olarak da ifade edilmektedir (Robbins, 1990: 53). Bireyin beklenti ve değer algılarının yükselmesiyle göstereceği çaba da artacak ve sonuçta elde edecek kazanımları da artacaktır. Kendi 
çıkarları doğrultusunda hareket eden yıkıcı lider, belirli bir noktadan sonra çalışanların beklentilerini karşılamaktan uzaklaşacaktır. Akman'a (2016) göre beklentisi karşılanmayan çalışanlar sinik davranışlar sergileyecektir. $\mathrm{Bu}$ kapsamda örgütsel sinizm, liderin çalışanlara verdikleri sözleri ve genel beklentileri yerine getirmemeleri sonucunda görülmektedir (Görmen, 2017: 366).

\section{3. Örgütsel Sapma}

Araştırmalarda örgütsel sapmanın çalışanlara yönelik olumsuz davranışlar arasında olduğu belirtilmekle birlikte anti sosyal davranışlar ile zararlı davranışların bütünü olarak da nitelendirilmektedir (Judge vd., 2006: 126). Bu kapsamda örgütsel sapma, örgüte veya örgüt çalışanlarına zarar verebilecek davranışlarda bulunma, işten kaçma, verilen görevi yanlış veya eksik yapma, sözlü ve fiziksel saldırı, hırsızlık gibi davranışlar olarak da görülmektedir (Spector ve Fox, 2002: 272; Bennett ve Robinson, 2003: 250). Örgütsel sapma çalışanların işlerini yapmalarını engelleyici faaliyetlerde bulunmalarıyla kendilerinden beklenen görevleri yapmamaları ve bu olumsuz davranışları bile isteye sergilemeleri olarak ifade edilebilir. Vardi ve Wiener (1996), bu görüşü destekler nitelikte örgütsel sapma davranışını, örgüt çatısı altında çalışanlara verilen görevleri kötüye kullanma biçimi olarak tanımlamaktadır. Kidwell Jr ve Kochanowski (2005: 137) örgütsel sapma davranışını sapkın bir davranış olarak nitelendirerek, çalışanların görevlerinde düşük çabalar sarf etmeleri, başkaldırma, sabotaj, dikkatsizlik, yalancılık ve hatta uyuşturucu ve alkol kullanımı ile taciz ve kumar alışkanlıklarını da içerdiğini belirtmektedir. Gruys ve Sackett (2003: 30), örgüt çalışanlarının örgütün yasal çıkarlarına karşı yapmış oldukları kastın da örgütsel sapma davranışı olduğunu ifade etmektedir.

Alan yazında örgütsel sapma kavramı birçok konuyla ilişkilendirilmekle birlikte, örgütsel sapmanın; iş tutumları, örgütsel öğrenme, örgütsel adalet, örgütsel vatandaşl1k gibi örgütü olumlu yönde etkileyen konularla ilişkilendirildiği ve bu olumlu davranışları negatif yönde etkilediği belirtilmektedir (Al-Aameri, 2000; Avc1, 2008; Shepherd vd., 2010; Çeken, 2012; Ayazlar ve Güzel, 2013; Polatçı vd., 2014; Yalap, 2016; Tufan ve Uğurlu, 2019; Erturk ve Ziblim, 2020). Ayrıca sapma kavramı duygusal zekâ ile (Demir, 2009) ve psikolojik sözleşme ile (İyigün, 2011; İyigün ve Çetin, 2012) de ilişkilendirilmektedir. Diğer yandan örgütsel sapma negatif konularla da ilişkilendirilmekte (Demir, 2009; Demir ve Tütüncü, 2010; Ariani, 2013; Ak ve Sezer, 2018; Akyüz ve Özyer, 2018; Bana, 2019; Gültaç, 2019) ve bu kavramlarla pozitif yönlü ilişkilerinin olduğu ifade edilmektedir.

$\mathrm{Bu}$ araştırma kapsamında örgütsel sapma, iş yeri saldırganlığı yaklaşımına dayandırılmaktadır. İş yeri saldırganlığı yaklaşımı ilk olarak Buss (1961) tarafından ortaya atılmış olup fiziksel-sözlü, aktif-pasif ve dolaylıdolaysız olmak üzere üçe ayrılmaktadır. Yaklaşıma göre fiziksel saldırganlık çalışanlara fiziksel olarak müdahale etme (dokunma, itme, dürtme), sözlü saldırganlık ise sözlü olarak (bağırma, azarlama, hakaret) bireylere müdahale etme durumudur. Doğrudan saldırganlık biçimi hedef bireye yönelik yapılan müdahale olup dolaylı saldırganlık ise hedef bireye dolaylı olarak başkaları yoluyla müdahale edilmesidir. Aktif müdahale bireyin hedefe yönelik zarar verici faaliyette bulunması olmakla birlikte pasif müdahale ise hedefin gereksinimlerine yönelik olumsuz müdahale biçimidir (Solmuş, 2005: 82; Hershcovis ve Barling, 2010; Chang ve Lyons, 2012).

\subsection{Yıkıcı Liderlik, Örgütsel Sinizm ve Örgütsel Sapma İlişkileri}

Alan yazında yıkıcı liderlik ile örgütsel sapma arasındaki etkileşimi inceleyen Çelebi'ye (2019) ait tek bir çalışmaya rastlanmış olup araştırmanın da model ve hipotezlerinde bu çalışmadan esinlenilmiştir. Çelebi (2019: 63) alan yazındaki bu kısıtlılık nedeniyle yıkıcı liderlik kavramı yerine yapıcı liderlik davranışlarını dikkate alarak yapıcı liderlik davranışları ile örgütsel sapma davranışlarını ele alan çalışmaları incelemiştir. Alan yazında bu etkileşimi ele alan çalışmalarda (Jaskyte, 2004; Waters ve Marzano, 2006; Çeken, 2012; Girgin Köse, 2013; Aksu, 2016; Fallatah vd., 2017; Akçit vd., 2018; Tufan ve Uğurlu, 2019) olumlu liderlik davranışlarının örgütsel sapmayı olumsuz etkilediğini, bu davranış türleriyle örgütlerde sapma davranışının azalacağı belirtilmektedir. Bu kapsamda yapıcı liderlik davranışının tersi olan yıkıcı liderliğin örgütsel sapmayı pozitif yönde etkileyeceği düşüncesiyle araştırmanın ilk hipotezi aşağıdaki şekilde kurgulanmıştır.

\section{H1: Ylkıcı liderliğin örgütsel sapma üzerinde pozitif yönlü anlamlı etkisi vardır.}

Alan yazında liderlik kavramı hakkında yapılan araştırmalar genelde liderliğin olumlu yönlerine vurgu yapmasına rağmen bazı araştırmaların liderliğin olumsuz yönlerine değindiği görülmektedir. Çelebi (2019: 61), liderliğin olumsuz yönlerini ele alan araştırmalarda yıkıcı liderliğin örgütsel sinizm etkileşimini inceleyen araştırmaların kısıtlı veya bulunmadığını belirtilmektedir. $\mathrm{Bu}$ nedenle ilgili araştırmacı liderliğin pozitif yönlerini araştıran kavramlarla örgütsel sinizm etkileşiminin ele alan araştırmaları inceleyerek genelleme yapmıştır. Alan yazında yapılan araştırmalarda yıkıcı liderlik kavramına benzer hatta aynı özellik gösteren toksik liderlik kavramı ile ilgili birçok araştırma bulunmakla birlikte toksik liderlik ile örgütsel sinizmin ilişkilendirildiği araştırmalarda (Dobbs ve Do, 2006; Lee ve Moon, 2011; Demirel, 2015; Çakarel vd., 2019; Dobbs ve Do, 2019; Çankaya ve Çiftçi, 2020; Ebrahimi vd., 2020) toksik liderlik ile örgütsel sinizm arasında pozitif ilişki bulunmuştur. Bu kapsamda Kırbaç (2013), liderliğin olumsuz yönü olan toksik liderlik hakkında yapılan araştırmalarda bu kişilerin; çalışanlarına davranışlarında güvensizlik, eşitsizlik, kızgınlık aşılayarak acı çektirme eğiliminde olduklarını, bu durumun çalışanlarda tükenmişlik ve bıkkınlık oluşturduğunu belirtmektedir. Andersson ve Bateman'a (1997: 450) göre toksik liderliğin sonucunda örgütsel sinizm ortaya çıkmakta ve bu durum örgütteki otoriteye karşı olumsuz davranışlar sergilemeye ve güvensiz bir tutum sergilenmesine neden olmaktadır. Bu bilgiler ışığında araştırmanın ikinci hipotezi aşağıdaki gibi oluşturulmuştur;

\section{H2: Yıkıcı liderliğin örgütsel sinizm üzerinde pozitif yönlü anlamlı etkisi vardır.}

Örgütsel sapma ile örgütsel sinizm arasındaki etkileşimi inceleyen alan yazında Shahzad ve Mahmood (2012) ile Çelebi'ye (2019) ait iki çalışmaya rastlanmıştır. Bu çalışmalarda örgütsel sinizm ile örgütsel sapma 
davranışlarının örgütü olumsuz etkileyen sapkın ve yıkıcı davranışlar olması sebebiyle birbirleriyle pozitif etkileşimleri olduğu belirtilmektedir. $\mathrm{Bu}$ kapsamda araştırmanın üçüncü hipotezi aşağıdaki biçimde kurgulanmıştır.

H3: Örgütsel sinizmin örgütsel sapma üzerinde pozitif yönlü anlamll etkisi vardır.

Araştırma kapsamında her üç değişkeni ele alan sadece bir araştırmaya (Çelebi, 2019) rastlanılmıştır. Bu araştırmanın bulgularında örgütsel sinizmin aracı rolü dikkate alınmıştır. Buna ek olarak örgütsel sinizmin aracı rol üstlendiği araştırmalarda (Gkorezis vd., 2015; Ceyhan ve Çiçek, 2020; Yildirim ve Ceyhan, 2020) ilgili değişkenlere aracı rol oynadığı belirlenmiştir. Alan yazında rastlanılan çalışmalar 1şı̆̆ında araştırmanın son hipotezinde örgütsel sinizmin aracı rolüne ilişkin hipotez aşağıdaki gibi kurgulanmıştır.

H4: Ylkıcı liderliğin örgütsel sapmaya etkisinde örgütsel sinizm aracı rol oynamaktadır.

$\mathrm{Bu}$ bilgiler 1şı̆̆ında, araştırmanın teorik modeli ve hipotezleri Çelebi'nin (2019) araştırmasından esinlenerek Şekil 1'deki gibi kurgulanmıştır. Modelde "yıkıcı liderlik" bağımsız değişken, "örgütsel sapma” bağımlı değişken ve "örgütsel sinizm” ise aracı değişken olarak kurgulanmıştır.

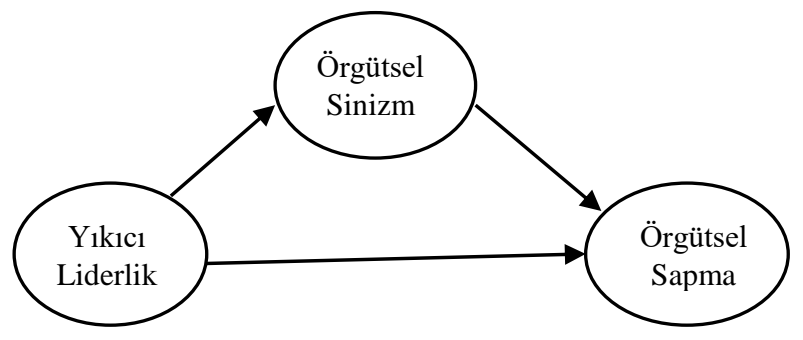

Şekil 1. Araştırma Modeli

\section{Yöntem}

\subsection{Evren ve Örneklem}

Çalışmanın evrenini Konya ilinde gıda üretim sektöründe faaliyet gösteren bir işletmenin çalışanları oluşturmaktadır. $\mathrm{Bu}$ doğrultuda işletmenin çalışanlarından tam sayım örnekleme yöntemiyle 320 çalışandan 283 kullanılabilir anket formu elde edilmiştir. Araştırmada tamsayım örnekleme yönteminin seçilmesinde amaç, evrenin tamamının incelenmesine araştırma yapmaktır (Tutar ve Erdem, 2020: 242). Elde edilen analiz edilebilir anket miktarına göre ulaşılan örneklem büyüklügü̈ \%88,4’tür. Bu orana göre örneklemin evreni temsil etme gücünün yeterli olduğu görülmektedir (Baş, 2013: 43).

Araştırma verileri 07.11.2019 - 19.11.2019 tarihleri arasında ilgili işletmeden elde edilmiştir. Araştırma kapsamında etik kurallara uyulmuştur.

\subsection{Veri Toplama Arac1}

Araştırmanın ilk ölçeği Shaw vd. (2011) tarafından oluşturulan ve Uymaz (2013) tarafından geliştirilip Türkçeye uyarlanan "Yıkıcı Liderlik Davranışı Ölçeğì" dir. Bu ölçek 23 ifadeden oluşmaktadır. Araştırmanın ikinci ölçeği olan "Örgütsel Sinizm Ölçeği" 14 ifadeden oluşmaktadır ve Brandes (1998) tarafindan geliştirilip Erdost vd. (2007) tarafından Türkçeye uyarlanmıştır. Araştırmanın son ölçeği olan "Örgütsel Sapma Ölçeğì" ise Bennett ve Robinson (2003) tarafından oluşturulup Avcı (2008) tarafından Türkçeye uyarlanmıştır. Bu ölçek 15 ifadeden oluşmaktadır. Bu ölçeklerin ölçümünde 5'li Likert ölçeği kullanılmıştır (1= Kesinlikle Katılmıyorum, 2= Katılmıyorum, 3= Kararsızım, 4= Katılıyorum, 5=Kesinlikle Katılıyorum).

\subsection{Geçerlilik ve Güvenirlik}

Araştırmada kullanılan ölçeklere yönelik yapılan güvenilirlik analizinde yıkıcı liderlik ölçeği için $\alpha=0.853$, örgütsel sinizm ölçeği $\alpha=0.857$ ve örgütsel sapma ölçeği $\alpha$ $=0.814$ olarak belirlenmiştir. $\mathrm{Bu}$ sonuçlara göre ölçeklerin güvenilir olduğu görülmektedir.

Araştırma modelinde ele alınan yıkıcı liderlik, örgütsel sinizm ve örgütsel sapma ölçeklerinin güvenilirlik ve geçerliliklerini belirleyebilmek için ölçüm modeline Doğrulayıcı Faktör Analizi (DFA) uygulanmıştır. Doğrulayıc1 faktör analizi sonucunda örgütsel sapma ölçeğindeki 15. soru, örgütsel sinizmdeki $1,6,8$ ve 11 numaralı sorular ile yıkıcı liderlik ölçeğindeki 1, 2, 4, 15, 20, 22 ve 23 numaralı soruların standartlaştırılmış faktör yüklerinin düşük olması nedeniyle analiz kapsamından çıkarılmıştır. Akabinde model tekrar test edilmiştir. Daha sonra tek faktörlü model uygulaması yapılarak araştırma modeli ile tek faktörlü model arasında karşılaştırma yapılmıştır. Elde edilen değerler Tablo 1'de gösterilmektedir.

Tablo 1. Model-Veri Uyum Değerleri

\begin{tabular}{lccccccccc}
\hline & $\mathrm{X}^{2}$ & $\Delta \mathrm{X}^{2}$ & $\mathrm{SD}$ & $\mathrm{X}^{2} / \mathrm{SD}$ & $\mathrm{GFI}$ & $\mathrm{NFI}$ & $\mathrm{CFI}$ & $\mathrm{TLI}$ & RMSEA \\
\hline $\begin{array}{l}\text { Tek faktörlü } \\
\text { model }\end{array}$ & 4092,79 & - & 702 & 5.83 & .410 & .436 & .480 & .451 & .118 \\
$\begin{array}{l}\text { Araştırma } \\
\begin{array}{l}\text { Modeli } \\
\text { p }<0.01\end{array}\end{array}$ & 941,23 & 3164,30 & 683 & 1,37 & .879 & .921 & .957 & .953 & .045 \\
\hline \\
$\quad$
\end{tabular}

Kaynak: Browne ve Cudeck, 1993; Marsh ve Hocevar, 1985; Tanaka ve Huba, 1985; Bentler ve Bonett, 1980; McDonald ve Marsh, 1990; Bentler ve Bonett, 1980

Tablo 1'deki doğrulayıcı faktör analizi sonucuna göre araştırma verileri 3 ölçme modeline dağıtılarak test edilmiştir. Modele ilişkin RMSEA, GFI, NFI, CFI, TLI ve $\chi 2 / \mathrm{SD}$ uyum indeksleri ile elde edilen sonuçlar ile iyi uyum geçerlilik ölçüleri gösterilmektedir. Tablo 1'de 3 faktörlü modele göre $\chi^{2}$ değerinin anlamlı olduğu belirlenmiştir $(\mathrm{p}<0.01)$. Ayrıca $\chi 2 / \mathrm{SD}$ değerinin $(1,37) 5$ 'in altında olması nedeniyle modelin geçerlilik açısından uyumlu olduğu 
görülmektedir. Araştırma modelleri uyum indeksleri GFI = $0.879, \mathrm{NFI}=0.921, \mathrm{CFI}=0.957, \mathrm{TLI}=0.953$ ve $\mathrm{RMSEA}=$ 0.045 olması nedeniyle modelin uyumlu olduğu görülmektedir. Buna ek olarak yine aynı tabloda (Tablo 1) tek faktörlü model ile araştırmanın üç faktörlü modeli arasında yapılan karşılaştırmada anlamlı farkı belirleyebilmek için $\chi^{2}$ değerlerine $\mathrm{Ki}$ Kare Testi uygulanmış ve iki değer arasında anlamlı fark belirlenmiştir. $\mathrm{Bu}$ sonuçlara göre araştırmada ortak yöntem sapmasının olmadığı görülmektedir (MacKenzie ve Podsakoff, 2012).

Tablo 2. Değişkenlere Ait Ortalama, Standart Sapma, Güvenirlilik ve Korelasyon Analizi Sonuçları

\begin{tabular}{lccccccc}
\hline & Ort & S. S & CR(t) & AVE & 1 & 2 & 3 \\
\hline Y1k1c1 Liderlik & 2,66 & 0,723 & 0,954 & 0,596 & - & & \\
Örgütsel Sapma & 2,75 & 0,770 & 0,933 & 0,567 & $0,675^{* *}$ & - & \\
Örgütsel Sinizm & 2,51 & 0,771 & 0,917 & 0,552 & $0,416^{* *}$ & $0,549 * *$ & - \\
\hline
\end{tabular}

Araştırma modeli ile değişkenlerin uyumluluğu ve ölçümü sağlayıp sağlamadığını belirlemek amacıyla yakınsama (convergent validity) ve ıraksama (discriminant validity) geçerlilik tekniklerinden yararlanılmıştır. Hair vd. (2006)'ne göre bir araştırmada ölçek maddelerinin faktör yüklerinin 0,5 değerinden yüksek olması araştırma modelinin ölçme ölçütünü sağladığını göstermektedir. Bu kapsamda araştırma ifade ölçeklerine ait maddelerin standartlaştırılmış faktör yükleri 0,5 değeri üzerindedir. Buna ek olarak, faktör yüklerinin parametrik değerleme noktasında t değerleri 6,47 ile 18,34 arasında değişmektedir. $\mathrm{Bu}$ değerlere göre araştırma modeli anlamlı olarak görülmektedir (Hair vd., 2006).

Tablo 2'de araştırma modelinin analizindeki ortalama açıklanan varyans (AVE) değerinin 0,5 değerinden yüksek olması yakınsama geçerliliğinin kanıtı olarak gösterilmektedir (Fornell ve Larcker, 1981). Bu kapsamda her üç ölçeğin AVE değerlerinin 0,5 değerinden yüksek olduğu görülmektedir. Ayırt edici geçerlilik (discriminant validity) için araştırma ölçeklerinin birbirleri arasındaki korelasyon değerlerinin 0,80'den düşük olması gerekmektedir (Kline, 2014). Tablo 2'ye göre, ilgili ölçeklerden elde edilen yapı güvenirliğinin (CR), her iki güvenirlik düzeyinin 0.70 'den yüksek olması ölçme sonuçlarının güvenirliğinin bir kanıtı olarak ifade edilmektedir (Nunnally, 1975; Fornell ve Larcker, 1981; Hair vd., 2006). Korelasyon analizi sonucunda; yıkıcı liderlik ile örgütsel sapma arasında pozitif yönlü $(r=0.675$, $\mathrm{p}<.01)$ bir ilişkinin olduğu görülmektedir. Aynı şekilde yıkıcı liderlik ile örgütsel sinizm arasında pozitif yönlü bir ilişki belirlenmiştir $(r=0.416, p<.01)$. Ayrıca örgütsel sapma ile örgütsel sinizm arasında pozitif yönlü bir ilişkinin olduğu da belirlenerek $(\mathrm{r}=0.549, \mathrm{p}<.01) . \quad$ Bu bulgulara göre değişkenler arasında pozitif yönlü ilişkilerin bulunduğu belirlenmiştir.

\section{Bulgular}

\subsection{Demografik Bulgular}

Araştırmadaki katılımcıların cinsiyet, eğitim düzeyi, yaş ve kıdem gibi demografik bulgulara göre; katılımcıların \%44,5'inin kadınlardan, \%55,4'ü erkeklerden oluşmaktadır. Yaş aralığına göre katılımcıların \%32,1 oranında, 36-45 yaş aralığında yoğunlaştığ 1 görülmektedir. Diğer yaş oranlarına göre katılımcıların \%12'si 18-25 yaş, \%29,3'ü 26-35 yaş, $\% 16,6$ 'sı 46-55 yaş ve $\% 9,9$ 'u ise 56 yaş ve üzeri personelleri kapsamaktadır. Katılımcıların medeni durumlarına bakıldığında \%62,1'inin evli, \%37,8'inin ise bekâr olduğu belirlenmiştir. Eğitim düzeylerine göre dağılım incelendiğinde katılımcıların \%42,7'sinin ilköğretim derecesinde olduğu ve bu derecede yoğunlaştıkları görülmektedir. Diğer dağılımlarda ise katılımcıların \%27,9'u önlisans ve \%28,3'ünün ise lisans derecesine sahip oldukları belirlenmiştir.

\subsection{Araştırma Hipotezlerinin Test Edilmesi}

Araştırma hipotezlerini test edebilmek için yapısal eşitlik modeli uygulanmıştır. Araştırmanın dördüncü hipotezinde yıkıcı liderliğin örgütsel sapmaya etkisinde örgütsel sinizmin arac1 rolü incelenmektedir. MacKinnon vd. (2007: 594)'a göre aracı değişken, iki değişken arasında bulunan neden sonuç ilişkisini belirlemek amacıyla kullanılan analiz yöntemidir. Baron ve Kenny (1986)'ye göre araştırmada aracılık etkisinin ölçülmesi için; 1) Bağımsız değişkenin aracı değişkene etkisinin bulunması gerekmektedir. 2) Bağımsız değişkenin bağımlı değişkene etkisinin olması gerekmektedir. 3) Aracı değişkenin bağımlı değişkene etkisinin olması gerekmektedir. Bu kapsamda değişkenler arasındaki etkinin belirlenebilmesi için değişkenlere yapısal eşitlik modeli uygulanmıştır. Tablo 3'te yapısal eşitlik modeli analizi sonucunda doğrudan etki sonuçları belirtilmektedir.

Tablo 3. Doğrudan etki

\begin{tabular}{lcccc}
\hline \multicolumn{1}{c}{ Değişkenler } & B & t değeri & SH & $\mathrm{p}$ \\
\hline Y1kıc1 Liderlik - Örgütsel Sinizm & .975 & 10.019 & .097 & $* * *$ \\
Y1kıc1 Liderlik - Örgütsel Sapma & .639 & 4.955 & .059 & $* * *$ \\
Örgütsel Sinizm - Örgütsel Sapma & .853 & 5.399 & .158 & $* * *$ \\
\hline Not: : s, standart beta; SH, standart hata; $* 0,05 * * 0,01 * * * 0,001$ düzeyinde anlamlıdır (çift-yönlü)
\end{tabular}

Tablo 3'e göre yıkıcı liderliğin örgütsel sinizm üzerinde pozitif yönlü anlamlı etkisinin olduğu belirlenmiştir $(\beta=.975$, $\mathrm{t}=10.019, \quad \mathrm{p}<0.001)$. H1 hipotezi desteklenmiştir.
Araştırmanın ikinci hipotezine göre yıkıcı liderliğin örgütsel sinizm üzerinde pozitif yönlü anlamlı etkisinin olduğu görülmektedir $(\beta=.639, \mathrm{t}=4.955, \mathrm{p}<0.001)$. H2 hipotezi 
desteklenmektedir. Son olarak örgütsel sinizmin örgütsel sapma üzerinde pozitif yönlü anlamlı etkisinin bulunduğu görülmektedir $(\beta=.853, \mathrm{t}=15.399, \mathrm{p}<0.001)$. Bu bulguya göre H3 hipotezi desteklenmektedir. Doğrudan etki akabinde aracı etkiye bakılmıştır (Tablo 5).

\begin{tabular}{|c|c|c|c|c|c|c|c|}
\hline & $\begin{array}{c}\text { Toplam } \\
\text { Etki }\end{array}$ & $\begin{array}{c}\text { Doğrudan } \\
\text { Etki }\end{array}$ & $\begin{array}{c}\text { Dolayl1 } \\
\text { Etki }\end{array}$ & Alt Sinır & Üst Sinır & $\mathrm{p}$ & Sonuç \\
\hline Y1kıcı Liderlik - Örgütsel Sinizm & 0.975 & 0.975 & - & - & - & - & \multirow{3}{*}{$\begin{array}{c}\text { Aracı etki var. } \\
\mathrm{R}^{2}: \% 87\end{array}$} \\
\hline Y1kıcı Liderlik - Örgütsel Sapma & 0.922 & 0.639 & 0.283 & 0.124 & 0.591 & 0.001 & \\
\hline Örgütsel Sinizm - Örgütsel Sapma & 0.853 & 0.853 & - & - & - & - & \\
\hline
\end{tabular}

Not: SH, standart hata; $* 0,05 * * 0,01 * * * 0,001$ düzeyinde anlamlıdır (çift-yönlü)

Tablo 4'e göre \%95 güven aralığında yıkıcı liderliğin örgütsel sapmaya etkisinde örgütsel sinizm aracı rol oynamaktadır $(\mathrm{p}=0.001)$. Analiz bulgusuna göre yıkıcı liderliğin örgütsel sapmaya aracı etki olmadan doğrudan etkisinin $(\beta=0.639)$ olduğu belirlenmiştir. Daha sonra arac1 değişken olan örgütsel sinizmin etkisi devreye girince yıkıcı liderliğin örgütsel sapma üzerindeki toplam etki 0.922 'ye yükselmektedir. $\mathrm{Bu}$ kapsamda örgütsel sinizmin aracı etkisinin $(\beta=0.283)$ olduğu belirlenmiştir. Güven aralığ 1 alt sınır $=0,554$ ile üst sınır $=0,872$ ve açıklanan varyans oranı ise $\% 87$ olarak belirlenmiştir. Bu kapsamda örgütsel sinizm değişkeninin yıkıcı liderlik ile örgütsel sapma arasında aracılık rol oynadığı görülmektedir $\left(\mathrm{R}^{2}=0.87 ; \mathrm{p}=0.001\right)$.

\section{Sonuç}

Araştırma, Konya ili gıda sektöründe faaliyet gösteren süt ürünlerini işleyen bir işletmede görev yapmakta olan çalışanlara yönelik yıkıcı liderlik, örgütsel sapma ve örgütsel sinizm etkileşimlerini belirleyebilmek için bir uygulama yapılmıştır. $\mathrm{Bu}$ kapsamda "Yıkıcl liderliğin örgütsel sapmaya etkisinde örgütsel sinizm aracl bir etkiye sahip midir?" sorusuna cevap aranmıştır. Araştırma sorusunu cevaplayabilmek amaciyla kurgulanan hipotezlerin tümünün desteklendiği belirlenmiştir.

Alan yazında yıkıcı liderlik konusu hakkında yapılan araştırmalarda (Padilla vd., 2007; Illies ve Reiter-Palmon, 2008; Shaw vd., 2011; Krasikova vd., 2013; Breevaart vd., 2014; Brandebo, 2020), örgütsel sinizm konusu hakkında yapılan araştırmalarda (Gkorezis vd., 2015; Erdogdu, 2018; Dobbs ve Do, 2019; Kwantes ve Bond, 2019; Van Oortmerssen vd., 2020; Aboramadan vd., 2020) ve örgütsel sapma konusunda yapılan araştırmalarda (Bennett ve Robinson, 2003; Judge vd., 2006; Mitchell ve Ambrose, 2007; İyigün ve Çetin, 2012; Aksu, 2016) her üç kavramın da örgütleri olumsuz yönde etkileyen ve çalışanların motivasyon ve verimliliklerini düşüren davranış türleri olduğu belirtilmektedir.

Araştırma bulgularına göre birinci hipotezde yıkıcı liderliğin örgütsel sapma üzerinde pozitif yönlü etkisinin olduğu belirlenmiştir $\quad(\mathrm{p}<.001)$. Burroughs $\quad$ (2001), sağlık personelleri üzerinde yaptığı araştırmada olumsuz liderlik davranışının çalışanlarda örgütsel sapmaya neden olduğunu belirterek liderliğin örgütler için önemli olduğunu belirtmiştir. Mackey vd. (2020) yaptıkları araştırmada örgütlerde yıkıcı liderliğe maruz kalan çalışanların sapkın davranışlara yöneldiğini belirlemişlerdir. Araştırmanın ikinci hipotezinde y1kıcı liderliğin örgütsel sinizm üzerinde pozitif yönlü etkisi belirlenmiştir $(p<.001)$. Lee ve Moon (2011) polisler üzerinde yaptığı araştırmada olumsuz liderlik davranışının örgütsel sinizmi pozitif yönde etkilediğini belirlemiştir. Börü vd. (2020), otomotiv sektöründe yaptığı araştırmada toksik liderlik ile sinizm arasında pozitif yönlü ilişki tespit etmiştir. Araştırmanın üçüncü hipotezinde örgütsel sinizmin örgütsel sapma üzerinde pozitif yönlü anlamlı etkisi olduğu görülmüştür $(\mathrm{p}<.001)$. Aboramadan vd. (2020), İtalya otelleri çalışanlarına yönelik yaptıkları araştırmada negatif liderlik davranışı olan narsist liderliğin örgütsel sinizim davranışını güçlendirdiğini belirleyerek olumsuz davranışın liderden gelmesiyle örgütlerde çalışanların negatif davranışlarda bulunabileceklerini belirlemişlerdir. $\mathrm{Bu}$ bulgulara göre araştırmada bütün hipotezler kabul edilmiştir. Shahzad ve Mahmood (2012) bankacılık sektöründe yaptığı araştırmada çalışanların örgütsel sinizm algıları ile örgütsel sapma algıları arasında kuvvetli bir ilişki olduğunu belirlemiştir. Çelebi (2019) araştırmasında örgütsel sinizmin örgütsel sapma davranışını güçlendirdiğini belirlemiştir. Sonuç olarak alan yazındaki ilgili bulgular ile bu araştırma kapsamında elde edilen bulgular örtüşmektedir.

Araştırmanın son ve dördüncü hipotezinde yıkıcı liderliğin örgütsel sapmaya etkisinde örgütsel sinizmin aracı rol oynadığ 1 belirlenmiştir $(\mathrm{p}=0.001)$. Çelebi (2019), yaptığ araştırmada yıkıcı liderlik davranışının örgütsel sapma üzerindeki etkisinde örgütsel sinizmin kısmi aracı rolünün olduğunu belirlemiştir. Bu kapsamda araştırmanın dolaylı etkisine yönelik elde edilen bulgunun da alan yazınla örtüştüğü görülmektedir.

Gıda sektöründeki çalışanların ürettikleri ürünlerin insan sağlığı açısından önemli olması nedeniyle araştırmanın gıda sektöründeki çalışanlara yönelik yapılması uygun görülmüş, gıda sektörü çalışanlarının görevlerinde verimli ve titiz çalışmalarıyla sağlıklı ürünler üretecekleri düşünülmüştür. Araştırma bulguları kapsamında yıkıcı liderlik davranışlarının çalışanlarda örgütsel sinizim ve örgütsel sapma gibi olumsuz örgütsel davranışları güçlendirdiği anlaşılmıştır. Bu çerçevede örgütlerde olumsuz davranışın liderden gelmesi çalışanları da olumsuz etkilemekte ve çalışanların diğer negatif örgütsel davranışlar olan psikolojik sözleşme ihlali, örgütsel sessizlik, sanal kaytarma gibi davranışlar sergilemelerine neden olabilecektir. Buna ek olarak olumsuz liderlik davranışının çalışanlarda negatif etkiler oluşturacağ edebilecekleri görülmektedir. $\mathrm{Bu}$ kapsamda örgütte çalışanlara değer veren ve onların duygularını olumlu yönde etkileyecek, adaletli liderlik davranışları geliştiren liderlerin başarılı olacakları söylenebilir.

Araştırmanın sadece gıda sektöründe faaliyet gösteren bir işletmede yapılması, örneklemin sadece bir işletmeden elde edilmesi ve sadece Konya ilinde uygulama yapılması araştırmanın kısıtları arasında gösterilmektedir. $\mathrm{Bu}$ 
kapsamda elde edilen bulgular sadece Konya ilinde ve gida sektörü ölçeğinde geçerli olmaktadır. Gelecekte yapılacak araştırmalarda; ilgili ölçeklerin farklı çalışma gruplarında uygulanmasıdır. Araştırma kapsamında aracı değişken olarak ele alınan örgütsel sinizmin düzenleyici rolünün de olup olmadığının incelenmesi de önerilmektedir. Ayrıca konuların nicel araştırma yönteminin yanı sıra nitel uygulama yapılarak elde edilecek bulgularla karşılaştırması ve yıkıcı liderliğin etkilerine yönelik örgütsel davranışın diğer konularıyla ilişkilendirilmesi de araştırmacılara öneri niteliğinde olmaktadır.

\section{Kaynakça}

Aasland, M. S., Skogstad, A., Notelaers, G., Nielsen, M. B., \& Einarsen, S. (2010). The prevalence of destructive leadership behaviour. British Journal of management, 21(2), 438-452.

Aboramadan, M., Turkmenoglu, M.A., Dahleez, K.A. and Cicek, B. (2020), "Narcissistic leadership and behavioral cynicism in the hotel industry: the role of employee silence and negative workplace gossiping," International Journal of Contemporary Hospitality Management, Vol. ahead-of-print No. ahead-of-print. https://doi.org/10.1108/IJCHM-042020-0348

Ak, M., \& Sezer, Ö. (2018). Kamu Personel Sisteminde Çalişanlarin Görevde Yükselmesinde Kayirmacilik Sorunu. Süleyman Demirel Üniversitesi İktisadi ve Idari Bilimler Fakültesi Dergisi, 23(Geybulla Ramazanoğlu Özel Sayıs1), 739-757.

Akatay, A., Yücekaya, P., \& Kisat, N. Ç. (2016). Yöneticilerin etik liderlik davranışlarının, örgütsel adalet ve sinizm üzerine etkileri: Çanakkale İl Emniyet Müdürlüğü'nde bir araştırma. Yönetim Bilimleri Dergisi, 14(28), 483-509.

Akçit, V., Barutçu, E., \& Akşit, İ. (2018). Kurt Lewîn'in Liderlik Tarzları ile Örgütsel Sapma İlişkisinin İncelenmesi. Suleyman Demirel University Journal of Faculty of Economics \& Administrative Sciences, 23(1), 209-225.

Akman, Y. (2016). Yıkııı liderlik ile mesleki tükenmişlik arasındaki ilişki: öğretmenler üzerine bir araştırma. Eğitimde Kuram ve Uygulama, 12(3), 627-653.

Aksu, A. (2016). Organizational Deviance and Multi-Factor Leadership. Educational Research and Reviews, 11(8), 589-597.

Akyüz, M., \& Özyer, K. (2018). Cinsiyet Ayrımcılığının Örgütsel Sapma Davranışları Üzerindeki Etkisinde Öz-yeterliliğin Aracılık Rolü: Sağlık Kurumlarında Bir Araştırma. Artvin Çoruh Üniversitesi Uluslararasi Sosyal Bilimler Dergisi, 4(2), 25-51.

Al-Aameri, A. S. (2000). Job satisfaction and organizational commitment for nurses. Saudi medical journal, 21(6), $531-535$

Alper, M., \& Çetin, C. (2018). Liderlik Türlerinin Whistleblowing İlişkisinin Avukatlar Açısından
İncelenmesi. Kırklareli Üniversitesi Sosyal Bilimler Dergisi, 2(1), 48-64.

Andersson, L. M., \& Bateman, T. S. (1997). Cynicism in the workplace: Some causes and effects. Journal of Organizational Behavior: The International Journal of Industrial, Occupational and Organizational Psychology and Behavior, 18(5), 449-469.

Appelbaum, S. H., Iaconi, G. D., \& Matousek, A. (2007). Positive and negative deviant workplace behaviors: causes, impacts, and solutions. Corporate Governance: The international journal of business in society, Vol. 7 No. 5 2007, 586-598.

Ariani, D. W. (2013). The relationship between employee engagement, organizational citizenship behavior, and counterproductive work behavior. International Journal of Business Administration, 4(2), 46-56.

Aslan, Ş. (2019). Geçmişten günümüze liderlik kuramları: Eğitim Yayınevi. 2. Baskı. Eğitim Yayınevi, 1, 25.

Avc1, N. (2008). Konaklama işletmelerinde örgütsel ögrenme, iş tutumlarl ve örgütsel sapma arasindaki ilişkinin analizi. DEÜ Sosyal Bilimleri Enstitüsü.

Ayazlar, G., \& Güzel, B. (2013). Örgütsel Adaletin Otel Çalışanlarının İşten Ayrılma Niyeti ve İşyerinde Sapma Davranışına Etkisi. Seyahat ve Otel İ̧letmeciliği Dergisi, 10(3). 6-23.

Bakan, İ., \& Doğan, İ. F. (2012). Hizmetkâr liderlik. Kahramanmaraş Sütçü İmam Üniversitesi İktisadi ve Ídari Bilimler Fakültesi Dergisi, 2(2), 1-12.

Bana, P. E. (2019). Hastanelerde rol çatışması ve sosyal iklimin örgütsel sapma davranışına etkisi. Marmara Üniversitesi Sağlik Bilimler Enstitüsü Doktora Tezi

Baron, R. M., \& Kenny, D. A. (1986). The moderatormediator variable distinction in social psychological research: Conceptual, strategic, and statistical considerations. Journal of personality and social psychology, 51(6), 1173.

Baş, T. (2013). Anket: anket nasıl hazırlanır?: Anket nasıl uygulanır?: anket nasıl uygulanır? : Seçkin yayıncılik.

Başar, U., \& Basım, H. N. (2018). Paradoksal liderlik modeli. Amme Idaresi Dergisi, 51(3), 121-153.

Bennett, R. J., \& Robinson, S. L. (2003). The past, present, and future of workplace deviance research. The state of the science (247-281). Lawrence Erlbaum Associates Publishers.

Bentler, P. M., \& Bonett, D. G. (1980). Significance tests and goodness of fit in the analysis of covariance structures. Psychological bulletin, 88(3), 588-606.

Biswas, S., \& Kapil, K. (2017). Linking perceived organizational support and organizational justice to employees' in-role performance and organizational cynicism through organizational trust. Journal of Management Development. 698-711.

Bolea, A., \& Atwater, L. (2020). Becoming a Leader: Nine Elements of Leadership Mastery: Routledge. 
Börü, D., Çakarel, T. Y., Ufacik, O. E., \& Arslan, G. (2020). Toksİk LİderlİğIn Örgütsel Sİnİzm Üzerİndekİ Etkİsİ: Otomotİv Sektöründe Bİr Araştirma. İktisadi İdari ve Siyasal Araştırmalar Dergisi, 5(12), 194216.

Brandebo, M. F. (2020). How contextual is destructive leadership? A comparison of how destructive leadership is perceived in usual circumstances versus crisis. International Journal of Organizational Analysis. 220-239.

Brandes, P. M. (1998). Organizational cynicism: Its nature, antecedents, and consequences. (Doktora Tezi), Cincinnati Üniversitesi.

Breevaart, K., Bakker, A. B., Hetland, J., \& Hetland, H. (2014). The influence of constructive and destructive leadership behaviors on follower burnout. Burnout at work: A psychological perspective, 102-121.

Browne, M. W., \& Cudeck, R. (1993). Alternative ways of assessing model fit. Testing structural equation models, 154, 136.

Burroughs, S. M. (2001). The role of dispositional aggressiveness and organizational injustice on deviant workplace behavior. ProQuest Information \& Learning,

Buss, A. H. (1961). The psychology of aggression: Wiley.

Cartwright, S., \& Holmes, N. (2006). The meaning of work: The challenge of regaining employee engagement and reducing cynicism. Human resource management review, 16(2), 199-208.

Ceyhan, S., \& Çiçek, H. (2020). Ortaöğretim Kurumlarında Görev Yapan Öğretmenlerin A Tipi Kişilik Özelliklerinin Tükenmişlik Üzerindeki Etkisinde Genel Sinizmin Araci Rolü. Abant Izzet Baysal Üniversitesi Eğitim Fakültesi Dergisi, 20(2), 888903.

Chang, C.-H. D., \& Lyons, B. J. (2012). Not all aggressions are created equal: A multifoci approach to workplace aggression. Journal of Occupational Health Psychology, 17(1), 79-92.

Charan, R. (2017). The High-potential Leader: How to Grow Fast, Take on New Responsibilities, and Make an Impact: John Wiley \& Sons.

Coker, T. P. (2020). Accelerating Leadership and Professional Development for Adults: Developing a New Measure for Assessing Kegan's Constructive Developmental Orders. Theses and Dissertations

Çakarel, T. Y., Elber Börü, D., Ufacık, O. E., \& Arslan, G. (2019). Toksik liderliğin örgütsel sinizm üzerindeki etkisi: Otomotiv sektöründe bir araştırma. Paper presented at the 4th EMISSC International Entrepreneurship and Social Sciences Congress, İstanbul, Türkiye, 29 - 30 Kasım 2019.

Çalışal, S., \& Yücel, L. (2019). Hizmetkâr liderlik: Refik Saydam örneği. Sağllk Akademisyenleri Dergisi, 6(3), 167-172.
Çankaya, M., \& Çiftçi, G. E. (2020). Hastane Çalişanlarinin Toksİk Lİderlík Ve Örgütsel Sİnİzm Algilarinin Örgütsel Bağliliklarina Etkİsİ. Hacettepe Să̆llk Idaresi Dergisi, 23(2), 273-298.

Çark, Ö., \& Marşap, A. (2019). Kurumsal Kaynak Planlama Kullanıcıları Açısından Sistemin Faydalarını Etkileyen Faktörler 1. [The Factors Affecting Benefits of Enterprise Resource Planning System from User Perception]. Third Sector Social Economic Review, 54(2), 992-1013. doi:http://dx.doi.org/10.15659/3.sektor-sosyalekonomi.19.05.1127

Çeken, H. (2012). Etik Liderlik Ve Örgütsel Adaletin Örgütsel Sapma Davranışları Üzerindeki Etkisi. Muğla Üniversitesi Sosyal Bilimler Enstitüsü Dergisi(28), 18-39.

Çelebi, F. (2019). Yıkıcı liderliğin örgütsel sapma davranışı üzerindeki etkisinde örgütsel sinizmin aracı rolü: Samsun ili sağlık sektöründe bir araştırma. Ondokuz Mayıs Üniversitesi, Sosyal Bilimler Enstitüsü, İşletme Ana Bilim Dalı (Doktora Tezi),

Çevik, A., \& Can, N. (2020). Öğretmenlerin Örgütsel Vatandaşlık ve Örgütsel Sinizm Davranışlarının Yordayıcısı Olarak Okul Yöneticilerinin Makamsal Güç Kaynakları. Academia Eğitim Araştırmaları Dergisi, 5(1), 13-30.

De Lima, A. P. (2020). 'How did I become a leader in my family firm?' Assets for succession in contemporary Lisbon financial elites. In Elites (31-51): Routledge.

Demir, M. (2009). Konaklama işletmelerinde duygusal zeka, örgütsel sapma, çalışma yaşamı kalitesi ve işten ayrılma eğilimi arasındaki ilişkinin analizi. DEÜ Sosyal Bilimleri Enstitüsü, Sosyal Bilimler Enstitüsü/Turizm İşletmeciliği Ana Bilim Dalı (Doktora Tezi).

Demir, M., \& Tütüncü, Ö. (2010). Ağırlama işletmelerinde örgütsel sapma ile işten ayrılma eğilimi arasındaki ilişki. Anatolia: Turizm Araştırmaları Dergisi, 21(1), 64-74.

Demirel, N. (2015). Öğretmen algılarına göre okul müdürlerinin toksik liderlik davranışları ile öğretmenlerin örgütsel sinizm tutumları arasındaki ilişki (Gaziantep Şehitkâmil ilçesi örneği). Yayımlanmamış Yüksek Lisans Tezi). Kahramanmaraş Sütçü Imam Üniversitesi, Gaziantep.

Dobbs, J. M., \& Do, J. J. (2019). The impact of perceived toxic leadership on cynicism in officer candidates. Armed Forces \& Society, 45(1), 3-26.

Dobbs, L. C. J. M., \& Do, L. C. J. (2006). Toxic Leadership And Cynicism. In Pursuit of Excellence: International Perspectives of Military Leadership (2006) Strategic Leadership Development: International Perspectives (2007) Professional Ideology \& Development, 119.

Düğer, Y. S. (2020). Lider-Üye Etkileşiminin Çalışan Sesliliği ve İşten Ayrılma Niyeti Üzerindeki Etkisi: 
Psikolojik Güçlendirmenin Düzenleyici Rolü. Gaziantep Üniversitesi Sosyal Bilimler Dergisi, 19(3), 1215-1236.

Ebrahimi, S. A., Eynali, M., \& Bagheri GaraBolagh, H. (2020). the Consequences of Toxic Leadership in Sport Teams: Mediation Role of Unit Civility.

Egide, N., \& Andala, H. O. (2020). School Leadership Types and Teachers' Empowerment in Public Secondary Schools in Rwanda. Journal of Education, 3(5), 5971.

Einarsen, S., Aasland, M. S., \& Skogstad, A. (2007). Destructive leadership behaviour: A definition and conceptual model. The Leadership Quarterly, 18(3), 207-216.

Erdogdu, M. (2018). Effect of Organizational Justice Behaviors on Organizational Silence and Cynicism: A Research on Academics from Schools of Physical Education and Sports. Universal Journal of Educational Research, 6(4), 733-741.

Erdost, H. E., Karacaoğlu, K., \& Reyhanoğlu, M. (2007). Örgütsel sinizm kavramı ve ilgili ölçeklerin Türkiye'deki bir firmada test edilmesi. 15. Ulusal Yönetim ve Organizasyon Kongresi Bildiri Kitabı, 514-524.

Eren, E. (2001). Yönetim ve Organizasyon, Beta Yayıncılık, 5. Baskl, Istanbul.

Erturk, A., \& Ziblim, L. (2020). Is the Perception of Organizational Deviance Affected by the Organizational Climate? Research in Schools. Eurasian Journal of Educational Research, 85, 1-22.

Fallatah, F., Laschinger, H. K., \& Read, E. A. (2017). The effects of authentic leadership, organizational identification, and occupational coping self-efficacy on new graduate nurses' job turnover intentions in Canada. Nursing outlook, 65(2), 172-183.

Farah, B., Elias, R., De Clercy, C., \& Rowe, G. (2020). Leadership succession in different types of organizations: What business and political successions may learn from each other. The Leadership Quarterly, 31(1), 101289. 1-21.

Ferres, N., \& Connell, J. (2004). Emotional intelligence in leaders: an antidote for cynicism towards change? Strategic Change, 13(2), 61-71.

Fornell, C., ve Larcker, D. F. (1981). Evaluating structural equation models with unobservable variables and measurement error. Journal of marketing research, 18(1), 39-50.

Gandolfi, F., \& Stone, S. (2016). Clarifying leadership: High-impact leaders in a time of leadership crisis. Revista de Management Comparat International, 17(3), 212-240.

Girgin Köse, S. (2013). Ortaokul öğretmenlerinin örgütsel sapma ve startejik liderlik arasındaki ilişki üzerine algllarl: İzmir ili örneği. DEÜ Eğitim Bilimleri Enstitüsü, Yüksek Lisans Tezi.
Gkorezis, P., Petridou, E., \& Krouklidou, T. (2015). The detrimental effect of machiavellian leadership on employees" emotional exhaustion: organizational cynicism as a mediator. Europe's journal of psychology, 11(4), 619-631.

Gnambs, T. (2019). Opinion leadership types or continuous opinion leadership traits? International Journal of Psychology, 54(1), 88-92.

Gökçe, S. G., Emhan, A., Özer, Z., \& Kaya, A. (2017). Sinizim, Kişilerarası Çatışma ve İşten Ayrılma Niyeti Arasındaki İlişkinin Analizi: Sağlık Sektöründe Bir Uygulama. Hacettepe Sağlık Idaresi Dergisi, 20(1), 93-108.

Görmen, M. (2017). Örgüt kültürünün örgütsel sinizm tutumları üzerine etkisi. Bartın Üniversitesi İktisadi ve İdari Bilimler Fakültesi Dergisi, 8(15), 363-388.

Gruys, M. L., \& Sackett, P. R. (2003). Investigating the dimensionality of counterproductive work behavior. International journal of selection and assessment, 11(1), 30-42.

Gül, H., \& Ağı̈öz, A. (2011). Mobbing ve örgütsel sinizm arasındaki ilişkiler: Hemşireler üzerinde bir uygulama. Afyon Kocatepe Üniversitesi İkisadi ve İdari Bilimler Fakültesi Dergisi, Arallk 2011, Volume 13, Issue 2, 27-47

Güldü, Ö., \& Aksu, N. E. (2016). Yıkıcı liderlik algısı ve mesleki tükenmişlik arasındaki ilișkide olumsuz duygu-durumun aracı rolü. Çalışma İlişkileri Dergisi, 7(2), 91-113.

Gültaç, A. S. (2019). Örgütsel Sapma Ve Nezaketsizlik Davranışları İlişkisinde Işsyerinde Dışlanmanın Aracı Rolü: Sağlık Kurumlarında Bir Araştırma. Sosyal Bilimler Enstitüsü, Yüksek Lisans Tezi.

Gün, İ., \& Aslan, Ö. (2018). Liderlik kuramları ve sağlık işletmelerinde liderlik. Journal of Health and Nursing Management, 5(3), 217-226.

Hair, J. F., Black, W. C., Babin, B. J., Anderson, R. E., ve Tatham, R. (2006). Multivariate data analysis . Uppersaddle River. In: NJ: Pearson Prentice Hall.

Hershcovis, M. S., \& Barling, J. (2010). Towards a multifoci approach to workplace aggression: A metaanalytic review of outcomes from different perpetrators. Journal of Organizational Behavior, 31(1), 24-44.

Hogan, R., \& Kaiser, R. B. (2005). What we know about leadership. Review of general psychology, 9(2), 169180 .

Hoobler, J. M., \& Brass, D. J. (2006). Abusive supervision and family undermining as displaced aggression. Journal of Applied psychology, 91(5), 1125-1133.

Hse, M. H. M. (2018). Leadership Is Everyone's Game: How to Become a Leader at Any Stage in Your Career. Canadian Journal of Medical Laboratory Science, 80(4), 24-24.

Illies, J. J., \& Reiter-Palmon, R. (2008). Responding destructively in leadership situations: The role of 
personal values and problem construction. Journal of Business Ethics, 82(1), 251-272.

İyigün, N. Ö. (2011). Psikolojik kontratın örgütsel sapma üzerindeki etkisinde kişilik özelliklerinin rolü ve bir araştırma. Marmara Üniversitesi Sosyal Bilimler Enstitüsü, Doktora Tezi.

İyigün, N. Ö., \& Çetin, C. (2012). Psikolojik kontratın örgütsel sapma üzerindeki etkisi ve ilaç sektöründe bir araştırma-The impact of psychological contract on organizational deviance and a research in pharmaceutical sector. Öneri Dergisi.C.10.S.37. Ocak 2012.15-29

James, M. S. (2005). Antecedents and consequences of cynicism in organizations: An examination of the potential positive and negative effects on school systems. The Florida State University College Of Business Electronic Theses, Treatises and Dissertations

Jaskyte, K. (2004). Transformational leadership, organizational culture, and innovativeness in nonprofit organizations. Nonprofit Management and Leadership, 15(2), 153-168.

Judge, T. A., Scott, B. A., \& Ilies, R. (2006). Hostility, job attitudes, and workplace deviance: Test of a multilevel model. Journal of Applied psychology, 91(1), 126-138.

Kaluza, A. J., Boer, D., Buengeler, C., \& van Dick, R. (2020). Leadership behaviour and leader selfreported well-being: A review, integration and metaanalytic examination. Work \& Stress, 34(1), 34-56.

Karacabey, M. F., Bellibaş, M. Ş., \& Adams, D. (2020). Principal leadership and teacher professional learning in Turkish schools: examining the mediating effects of collective teacher efficacy and teacher trust. Educational Studies, 1-20.

Karacaoğlu, K., \& İnce, F. (2012). Brandes, Dharwadkar ve Dean'in (1999) örgütsel sinizm ölçeği Türkçe formunun geçerlilik ve güvenilirlik çalışması: Kayseri Organize Sanayi Bölgesi Örneği. Business \& Economics Research Journal, 3(3). 77-92.

Kasalak, G., \& Aksu, M. (2016). Örgütler nasıl zehirlenir? Öğretim elemanlarının örgütsel toksisite algıları. Hacettepe Üniversitesi Eğitim Fakültesi Dergisi, 31(4), 676-694.

Kaya, L. (2020). Örgütsel adalet ve örgütsel sinizm ilişkisi. Pamukkale Üniversitesi Sosyal Bilimler Enstitüsü Yüksek Lisans Projesi İsletme Ana Bilim Dalı Yönetim ve Organizasyon Programı

Kidwell Jr, R. E., \& Kochanowski, S. M. (2005). The morality of employee theft: Teaching about ethics and deviant behavior in the workplace. Journal of management education, 29(1), 135-152.

Kim, Y.-J. (2017). Self-Leadership Types of Nursing Students. Research Journal of Pharmacy and Technology, 10(7), 2350-2354.
Kırbaş, M. (2013). Eğitim Örgütlerinde Toksit Liderlik, Inönü Üniversitesi, Eğitim Bilimleri Enstitüsü (Yüksek lisans tezi, Malatya).

Kline, P. (2014). An easy guide to factor analysis: Routledge.

Krasikova, D. V., Green, S. G., \& LeBreton, J. M. (2013). Destructive leadership: A theoretical review, integration, and future research agenda. Journal of management, 39(5), 1308-1338.

Kwantes, C. T., \& Bond, M. H. (2019). Organizational justice and autonomy as moderators of the relationship between social and organizational cynicism. Personality and Individual Differences, 151, 109391. 1-10.

Lee, C. H., \& Moon, J. (2011). Effects of officers' cynicism and their perception of managerial leadership on COP activities among South Korean police officers. Policing: An International Journal of Police Strategies \& Management. 31-48.

Mackey, J. D., Ellen III, B. P., McAllister, C. P., \& Alexander, K. C. (2020). The dark side of leadership: A systematic literature review and meta-analysis of destructive leadership research. Journal of Business Research.

MacKinnon, D. P., Fairchild, A. J., \& Fritz, M. S. (2007). Mediation analysis. Annu. Rev. Psychol., 58, 593614.

Marsh, H. W., \& Hocevar, D. (1985). Application of confirmatory factor analysis to the study of selfconcept: First-and higher order factor models and their invariance across groups. Psychological bulletin, 97(3), 562-582.

McDonald, R. P., \& Marsh, H. W. (1990). Choosing a multivariate model: Noncentrality and goodness of fit. Psychological bulletin, 107(2), 247-255.

McKenna, B., \& Rooney, D. (2019). Wise leadership. In R. J. Sternberg \& J. Glück (Eds.), The Cambridge handbook of wisdom (p. 649-675). Cambridge University Press. https://doi.org/10.1017/9781108568272.030.

MacKenzie, S. B., ve Podsakoff, P. M. (2012). Common method bias in marketing: Causes, mechanisms, and procedural remedies. Journal of retailing, 88(4), 542555.

Mehmet, İ., Bedük, A., \& Aydoğan, E. (2004). Örgütlerde Takim Çalişmasina Yönelik Etkin Liderlik Nitelikleri. Selçuk Üniversitesi Sosyal Bilimler Enstitüsü Dergisi(11), 423-446.

Mitchell, M. S., \& Ambrose, M. L. (2007). Abusive supervision and workplace deviance and the moderating effects of negative reciprocity beliefs. Journal of Applied psychology, 92(4), 1159-1178.

Nunnally, J. C. (1975). Psychometric theory-25 years ago and now. Educational Researcher, 4(10), 7-21.

Omar, Z., Mokhtar, M., \& Hamzah, S. R. a. (2015). Prevalence of workplace bully in selected public service agency in Malaysia: Do destructive leadership 
behaviour matters. International Journal of Education and Training, 1(1), 1-9.

Özgen, F. Ö., \& Turunç, Ö. (2017). Örgütsel Adalet-Sinizm Ilişkisinde Kişi Örgüt Uyumunun Rolü: Eğitim Sektöründe Bir Araştirma. Uluslararası İktisadi ve Idari Bilimler Dergisi, 3(2), 80-96.

Özgener, Ş., Ögüut, A., \& Kaplan, M. (2008). İşgören-işveren ilişkilerinde yeni bir paradigma: Örgütsel sinizm. Örgütsel Davranışta Seçme Konular: Organizasyonların Karanlı Yönleri ve Verimlilik Azaltıcı Davranışlar,(İçinde, M. Özdevecioğlu, H. Karadal (Ed.)(1. Baskı sy. 54-68) Ankara: Ilke Yayınevi.

Padilla, A., Hogan, R., \& Kaiser, R. B. (2007). The toxic triangle: Destructive leaders, susceptible followers, and conducive environments. The Leadership Quarterly, 18(3), 176-194.

Park, E.-M., Seo, J.-H., \& Ko, M.-H. (2016). The effects of leadership by types of soccer instruction on big data analysis. Cluster computing, 19(3), 1647-1658.

Petrone, P. (2020). How to become a leader? Revista Colombiana de Cirugía, 35(1), 14-16.

Polatçı, S., Özçalık, F., \& Cindiloğlu, M. (2014). Üretkenlik karşıtı iş davranışı ve örgütsel vatandaşlık davranışı üzerinde kişi-örgüt uyumunun etkileri. Ömer Halisdemir Üniversitesi İktisadi ve İdari Bilimler Fakültesi Dergisi, 7(3), 1-12.

Reyhanoğlu, M., \& Akın, Ö. (2016). Toksik liderlik örgütsel sağlı̆̆1 olumsuz yönde tetikler mi? Insan Ve Toplum Bilimleri Araştirmalari Dergisi Cilt: 5, Sayı: 3, 2016 Sayfa: $442-459$

Robbins, B., \& Davidhizar, R. (2020). Transformational leadership in health care today. The Health Care Manager, 39(3), 117-121.

Robbins, S. P. (1990). Organization Theory: Structures, Designs, And Applications, 3/e: Pearson Education India.

Samat, L. (2020). Algllanan Örgütsel Destek Ve Örgütsel Sinizm Arasındaki Illişkinin İncelenmesi: Bir Uygulama. Erzincan Binali Yıldırım Üniversitesi, Sosyal Bilimler Enstitüsü, Yüksek Lisans Tezi.

Sarıçam, E. (2017). Lider yönetici: İyi yönetici nasıl olunur. In: İstanbul: AZ (A'dan Z'ye İyi Kitaplar) Yayınları.

Sarto, F., \& Veronesi, G. (2016). Clinical leadership and hospital performance: assessing the evidence base. BMC health services research, 16(2), 85-97.

Schyns, B., \& Hansbrough, T. (2010). When leadership goes wrong: Destructive leadership, mistakes, and ethical failures: IAP.

Serinikli, N. (2020). Sağlık Çalışanlarında İş Özerkliği ve İş Performansı Arasındaki İlişkide Örgütsel Sinizm ve Yaşam Tatmini Seri Çoklu Arabuluculuğu. Işsletme Araştırmaları Dergisi, 12(2), 1693-1711.

Shahzad, A., \& Mahmood, Z. (2012). The mediatingmoderating model of organizational cynicism and workplace deviant behavior: Evidence from banking sector in Pakistan. Middle-East Journal of Scientific Research, 12(5), 580-588.

Shaw, J. B., Erickson, A., \& Harvey, M. (2011). A method for measuring destructive leadership and identifying types of destructive leaders in organizations. The Leadership Quarterly, 22(4), 575-590.

Shepherd, D. A., Patzelt, H., \& Haynie, J. M. (2010). Entrepreneurial spirals: Deviance-amplifying loops of an entrepreneurial mindset and organizational culture. Entrepreneurship theory and practice, 34(1), 59-82.

Solmuş, T. (2005). İş Yaşamında Duygular Ve Kişilerarası İlişkiler: Öfke-Saldırganlık Ve Romantik İlişkiler. ISGUC The Journal of Industrial Relations and Human Resources, 6(1).

Spector, P. E., \& Fox, S. (2002). An emotion-centered model of voluntary work behavior: Some parallels between counterproductive work behavior and organizational citizenship behavior. Human resource management review, 12(2), 269-292.

Suyono, J., Sawitri, H. S. R., Sunaryo, S., Mansur, A. S., \& Risgiyanti. (2020). Follower characteristics, obedience, and constructive resistance: the role of coproduction leadership. International Journal of Trade and Global Markets, 13(2), 182-198.

Şamdan, T., \& Baskan, G. A. (2019). Öğretmenlerin Algılarına Göre Örgütsel Adalet ve Örgütsel Sinizm Arasındaki İlişkinin İncelenmesi. Pamukkale Üniversitesi Eğitim Fakültesi Dergisi, 47, 17-40.

Tabak, A., Sigri, Ü., \& Türköz, T. (2013). Öz Liderlik Ölçeginin Türkçeye Uyarlanmasi Çalismasi. Bilig, 67, 213-246.

Tanaka, J. S., \& Huba, G. J. (1985). A fit index for covariance structure models under arbitrary GLS estimation. British journal of mathematical and statistical psychology, 38(2), 197-201.

Telli, E., Ünsar, S. A., \& Adil, O. (2012). Liderlik davranış tarzlarının çalışanların örgütsel tükenmişlik ve işten ayrılma eğilimleri üzerine etkisi: konuyla ilgili bir uygulama. Ejovoc (Electronic Journal of Vocational Colleges), 2(2), 135-150.

Tepper, B. J., Moss, S. E., Lockhart, D. E., \& Carr, J. C. (2007). Abusive supervision, upward maintenance communication, and subordinates' psychological distress. Academy of Management Journal, 50(5), 1169-1180.

Thoroughgood, C. N., Padilla, A., Hunter, S. T., \& Tate, B. W. (2012). The susceptible circle: A taxonomy of followers associated with destructive leadership. The Leadership Quarterly, 23(5), 897-917.

Topaktaş, G. (2020). Sağllk Kurumlarl Yöneticilerinin Algılanan Hizmetkâr Liderlik Özelliklerinin, Lider Etkililiği Ve Kurum Performans Göstergeleri Üzerindeki Etkisi. (Doktora Tezi), Hacettepe Üniversitesi Sosyal Bilimler Enstitüsü Sağlık Yönetimi Anabilim Dalı. 
Tufan, C., \& Uğurlu, Ö. Y. (2019). Otantik Liderlik Ve Örgütsel Sapma Davranışı Arasındaki İlişkide Örgütsel Öğrenme Kültürünün Aracılık Etkisi: Türkiye İlaç Sektöründe Bir Araştırma. Business \& Management Studies: An International Journal, 7(1), 467-495.

Tutar, H. (2016). Örgütsel davranış: Örgüt teorileri ve çağdaş yaklaşımlar açısından. Ankara: Detay Yayıncılık.

Tutar, H., \& Erdem, A. T. (2020). Örnekleriyle Bilimsel Araştirma Yöntemleri ve Spss Uygulamaları, Seçkin Yayncilik.

Tüysüz, B. (2007). Öğrenci liderliği programı’nın 6. sınıf öğrencilerinin liderlik rolleri ve davranışlarına etkisinin incelenmesi. Marmara Üniversitesi Eğitim Bilimleri Enstitüsü, Doktora Tezi

Uymaz, A. (2013). Yıkıcı Liderlik Ölçeği Geliştirme Çalışması. İstanbul Üniversitesi İşletme Fakültesi İşletme İktisadı Enstitüsü Yönetim Dergisi, 24(75), 37-57.

Uzunbacak, H. H., Yıldız, A., \& Uzun, S. (2019). Toksik Liderliğin Çalışanların Tükenmişlik Düzeylerine Etkisi. Anemon Muş Alparslan Üniversitesi Sosyal Bilimler Dergisi, 7(1), 211-219.

Van Oortmerssen, L. A., Caniëls, M. C., \& Van Assen, M. F. (2020). Coping with work stressors and paving the way for flow: Challenge and hindrance demands, humor, and cynicism. Journal of Happiness Studies, 21(6), 2257-2277.

Vardi, Y., \& Wiener, Y. (1996). Misbehavior in organizations: A motivational framework. Organization science, 7(2), 151-165.
Vice, S. (2011). Cynicism and morality. Ethical Theory and Moral Practice, 14(2), 169-184.

Vroom, V. H. (1964). Work and motivation. new york: John willey \& sons. Inc. VroomWork and Motivation1964.

Wade, M., \& Obwegeser, N. (2019). How to Choose the Right Digital Leader for Your Company. MIT Sloan Management Review, 60(4), 1-4.

Waters, J. T., \& Marzano, R. J. (2006). School district leadership that works: The effect of superintendent leadership on student achievement: Mid-continent Research for Education and Learning (McREL) Denver^ ${ }^{\wedge}$ CO CO.

Yalap, O. (2016). Çalışanların örgütsel adalet algılamalarının örgütsel sapma davranışları üzerinde etkisi: Tekstil sektöründe bir araştırma. Yayımlanmamış Yüksek Lisans Tezi. Gaziosmanpaşa Üniversitesi Sosyal Bilimler Enstitüsü, İstanbul.

Yeşil, A. (2016). Liderlik ve Motivasyon Teorilerine Yönelik Kavramsal Bir İnceleme| A Theoretical Research on Leadership and Motivation Theories. Uluslararası Akademik Yönetim Bilimleri Dergisi, 2(3). 150-180.

Yildirim, M., \& Ceyhan, S. (2020). Çalışma Yaşam Kalitesinin İşten Ayrılma Niyetine Etkisinde Örgütsel Sinizmin Aracılık Rolü. Anemon Muş Alparslan Üniversitesi Sosyal Bilimler Dergisi, 8(4), 1175-1184.

Yıldız, K. (2013). Örgütsel Bağlılık İle Örgütsel Sinizm Ve Örgütsel Muhalefet Arasındaki İlişki. Electronic Turkish Studies, 8(6). 853-879 
Equation Model Analysis, Chi-Square Difference Tests, and Correlation Analysis analyses were applied to the research data.

\section{Extended Abstract}

\section{Aim and Scope}

Employees in organizations spend most of their time at their workplaces. In order for employees to work efficiently in organizations, they must work in positive organizational environments. For this, organizations must be led by positive leaders. This research focuses on the negative organizational behavior issues that destructive leadership behavior seen as negative leadership behavior may cause in organizations. It is expected that organizational deviation and organizational cynicism behaviors will increase, especially in employees who encounter destructive leadership behavior. In this context, the research problem; is the increase of negative organizational behaviors caused by negative leadership behavior in employees day by day, and these negative behaviors affect organizations negatively. Purpose of the research; to analyze destructive leadership interactions, organizational deviation, and organizational cynicism. Research question; It was determined as "Does organizational cynicism have a mediating effect on the effect of destructive leadership on the organizational deviation." The theoretical basis of the research regarding the destructive leadership variable is based on behavioral theory. The theoretical basis of organizational cynicism is based on the expectation theory. The theoretical basis of the organizational deviation variable is based on the workplace aggression theory.

\section{Methods}

The research, which was designed according to the relational scanning model, one of the general scanning models, was constructed with the quantitative research method. The study was conducted on a sample of employees $(n=283)$ of a business operating in the food industry in Konya (Turkey). The data were obtained from the company employees with the full count sampling method through the questionnaire form. In the event that food industry workers sabotage their jobs, human health is affected more than other industry workers. In this context, the research sample was made in the food sector. Within the scope of the study, "destructive leadership" was constructed as the independent variable, "organizational deviation" as the dependent variable, and "organizational cynicism" as the mediator variable. Statistical analysis was applied to the research data with SPSS and AMOS programs. Cronbach Alpha coefficient test was applied to determine the reliability of the scales. Confirmatory Factor Analysis was applied to the research data to determine the research model validity. Structural

\section{Findings}

The following findings were obtained from the analysis of the findings obtained from the relevant business within the scope of the research;

- It has been determined that destructive leadership positively affects organizational deviation $(\mathrm{p}<.001)$.

- The positive effect of destructive leadership on organizational cynicism has been determined $(\mathrm{p}<.001)$.

- The positive effect of organizational cynicism on organizational deviation has been determined $(\mathrm{p}<.001)$.

- It has been determined that organizational cynicism played a mediating role in the effect of destructive leadership on organizational deviation ( $R 2=0.87$; $\mathrm{p}=0.001$ ).

\section{Conclusion}

In this study conducted with the sample of food sector employees, it was understood that destructive leadership behaviors strengthen negative organizational behaviors such as organizational cynicism and organizational deviation. In this context, negative behavior in organizations coming from the leader will also affect the employees negatively. In this context, employees exposed to negative leadership behaviors are also likely to exhibit organizational cynicism and organizational deviation behaviors and other negative organizational behaviors such as violation of psychological contract, organizational silence, and virtual loafing. It is also seen that negative leadership behavior will negatively affect employees, and these employees may even sabotage their duties. Conducting the research sample for food sector workers is also the idea that if these people sabotage their jobs, it will affect human health more negatively than other sector employees. In this context, it can be said that leaders who value the employees in the organization and develop fair leadership behaviors that will positively affect their emotions will be successful. In future research; It is the application of the relevant scales in different study groups. It is also suggested to examine whether organizational cynicism, which is considered a mediator variable, has a regulatory role in the study's scope. Besides, it is also a suggestion for researchers to compare the subjects with the findings to be obtained through the qualitative and quantitative research methods and associate them with other organizational behavior issues towards destructive leadership. In future research; It is the application of the relevant scales in different study groups. It is also suggested to examine whether organizational cynicism, which is considered a mediator variable, has a regulatory role in the study's scope. Also, it is a suggestion for researchers to compare the subjects with the findings to be obtained through the qualitative application and the quantitative research method and to associate them with other issues of organizational behavior towards the effects of destructive leadership. 